\title{
"But You Wouldn't Have the Gumption to Use It": Bonnie and Clyde and the Sexual Revolution
}

\section{Jana Kay Lunstad}

Narratives of the gangster film genre have consistently centered on the story of the male members of the Mafia family who attain their goals of wealth, power, and providing for their families, through criminal and violent acts. While critics such as Thomas Ferraro, William Simon, and Stella Bruzzi have focused on various aspects of the gangster story, such as patriarchal structure, ethnic and minority portrayals, family relationships, and even clothing styles, the role of women in gangster films has been a largely neglected subject. ${ }^{1}$ In this article I argue for the centrality of female characters in understanding the ideological and formal workings of the gangster genre. ${ }^{2}$ This remedies an oversight in genre film criticism, as well as adds substantially to feminist investigations of female figurability and visibility.

The traditional gangster narrative follows the progress of one male individual as he strives to fulfill the expectations placed on him by a patriarchal society. The gangster's central preoccupation of living out the American dream of economic success and power in a capitalist system, and his passionate drive to prevail, put him at odds with society's efforts to maintain social order. Because this familiar plot line focuses on the male characters, the women in the films are generally seen as narrative constructs who simply move the story along. As Laura Mulvey in "Visual Pleasure and Narrative Cinema," suggests:

\footnotetext{
Woman ... stands in patriarchal culture as a signifier for the male other, bound by a symbolic order in which man can live out his fantasies and obsessions through linguistic command by imposing them on the silent image of woman still tied to her place as bearer, not maker of meaning. ${ }^{3}$
}

The image of the matronly wife in a plain black dress serving spaghetti and upholding traditional family values, or the pampered mistress who spends the gangster's money and draws attention to his sexual prowess and power, illustrates this concept of woman as a cultural signifier. Seen as silent and passive characters, whose meaning is dependent on the male characters, these women become as predictable in the films as the familiar iconography of the gangster's black suit and gattling gun. As long as the female characters act in accordance with the rules imposed by the dominant males they are allowed to 
continue to occupy their prescribed space, but any aberration or failure to negotiate the spheres of wife or mistress leads to isolation and destruction.

Because audiences have come to expect these women to function as mere narrative devices, mediating the gangster's goal of rising to power and his means of doing so, the complexity of female characters has long been overlooked. Although these women seem to move around in the background and periphery of the narratives, they in fact exist beyond the formal aspects of the film genre and deserve to be foregrounded. A close reading of these characters will show how the women act as an index for marking the evolution of the genre. This can be achieved by examining how these characters fit in to, reflect, and mediate the political and cultural context of the period in which the films were made; changes in the genre may be identified by analyzing why and how women were depicted in different ways at different historical junctures.

The 1960 s was a critical decade in this history, during which national attention focused on women and the women's movement. As women fought to assert their right to equality in the workplace, the government, and the bedroom, society's notions of femininity, masculinity, and appropriate gender roles began to shift. The media played a central role in how people perceived the women's movement and the sexual revolution, and Hollywood genre films were no exception. In the 1967 film Bonnie and Clyde, director Arthur Penn examines issues such as women's struggle to discover a voice, male and female sexuality, criminality, and masculinity. In doing so, he rewrites the stories of the historical outlaws Bonnie and Clyde and manipulates the gangster genre, and specifically the sub-genre of the rural bandit film. In order to understand how Penn utilizes the genre to recreate historical characters into sixties icons, it is necessary to understand the gangster genre's development.

The history of the genre reaches back several decades and Jack Ellis explains that film genres emerged from Hollywood's studio era of the 1930s "because of the requirements of mass productions and popular appeal."4 Although genres came about because of the vertical control that studios maintained over all stages of production, distribution, and exhibition, and therefore the requirements of product differentiation, they retained their popularity even after the breakdown of the original studio system. The audience's familiarity with conventional story lines and standard iconographic images typical to westerns, musicals, horror films, or gangster films allows directors and screenwriters to utilize a genre to express contemporary cultural concerns. It seems that the story lines would become trite as they are repeated, but Thomas Schatz reminds us that, 
with repeated viewing ... the genre's narrative pattern comes into focus and the viewer's expectations take shape. And when we consider that the generic pattern involves not only narrative elements (character, plot, setting) but thematic issues as well, the genre's socializing influence becomes more apparent. ${ }^{5}$

In other words, while the formal elements of a genre are repeated, the ideological content of every genre film changes according to the time in which the film was made and thus mediates the audience's cultural beliefs and concerns. Because of a genre's ability to adapt in order to reflect contemporary cultural interests, it serves as an excellent tool to chart not only the formal evolution of films but also as a means to understand shifts in ideological thought. As Andrew Tudor suggests, "The crucial factors which distinguish a genre are not only characteristics inherent to the films themselves; they also depend on the particular culture within which we are operating."

A genre's connection to culture was an all-important factor in the rise and fall of the gangster film. Gangster films gained popularity with the three monumental films Little Caesar (1930), The Public Enemy (1931), and Scarface, Shame of the Nation (1932). ${ }^{7}$ One of the draws of the genres was the new sound and editing techniques that allowed filmmakers to depict the violence more realistically: the sounds of screeching tires and automatic weapons being fired from fast-moving vehicles turned the gangster film into a visual spectacle. This new film technology only added to the gangster's show of glamour and wealth that initially attracted Depression era audiences in need of escapism. As filmmakers presented the gangsters' lifestyle, a series of visual patterns, or icons, emerged that allowed audiences to immediately recognize the genre.

Unlike the ever-changing ideology reflected in movies, the iconography of the gangster film has stayed relatively the same over the genre's sixty-year life span. Robert Warshow argues that while films do mediate history, aesthetically they refer to each other:

Moreover, the relationship between the conventions which go to make up such a type and the real experience of its audience or the real facts of whatever situation it pretends to describe is only of secondary importance and does not determine its aesthetic force. It is only in an ultimate sense that the type appeals to previous experience of the type itself: it creates its own field of reference. ${ }^{8}$

This idea of films referring back to each other, rather than to history, 
appears in several different films over a number of years. For example, Tony in Little Caesar is shot by fellow gang members while walking up the steps of the church to confess to his priest. After the shots ring out, Tony's body falls across the steps. This scene is echoed in The Godfather I when, while Michael is becoming godfather to Connie's baby, rival Mafia members are being executed. ${ }^{9}$ Two men are walking down steps that recall the church steps in Little Caesar, and when they are killed their bodies fall in the same manner. Another useful example is found in the 1983 version of Scarface staring Al Pacino. ${ }^{10}$ The movie is a remake of the 1932 Scarface, but Pacino's character's name is Tony Montana, which is a combination of Tony Camonte from the original film and the Mafia chieftain Pete Montana from Little Caesar. Another more recent example of self-reference can be found in Get Shorty (1995). "Alex Rocco, who plays Mo Green, a character who is shot in the face while getting a massage in The Godfather I, shows up in this current film. His character, Buddy, in a scene that mirrors The Godfather I, lies on his stomach getting a massage. But instead of getting killed, he explains to another wise guy that he cannot kill a "made man." This kind of self-referentiality creates an aesthetic dialogue within each genre, foregrounding questions of revision and homage.

An examination of how the gangster genre refers to itself thematically and visually in the portrayal of the female characters illuminates how the genre has evolved over the years. Critics have focused on how women function formally in the films by how they support the leading male characters, but little attention has been paid to how the repeated formal use of these characters has affected the genre itself. For example, in "The Thematic Paradigm," Robert Bray suggests that throughout the history of American cinema, characters and plots consistently revolve around binary oppositions. In his analysis of the outlaw/hero relationships he argues:

Women were avoided as representing the very entanglements that tradition sought to escape: society, the "settled life," confining responsibilities. The outlaw hero sought only uncompromising relationships, involving either a 'bad' women (whose morals deprived her of all right to entangling domesticity) or other males (who themselves remain independent). Even the 'bad' woman posed a threat since marriage often uncovered the clinging 'good' girl underneath. Typically therefore, American stories avoided this problem by killing off the 'bad' woman before the marriage could transpire. Subsequently, within the all-male group, women became taboo except as objects of lust. ${ }^{12}$ 
While Bray's argument does cover a broad expanse of American outlaw films, he neglects the genre of the American gangster film in which the good girl/bad girl dichotomy does not exist to threaten the gangster's independence, but rather provides the impetus behind his criminal lifestyle. The gangster's main motivation seems to be one of material advancement, but the men in this genre consistently insist that their desire to protect and provide for their family - both their Mafia family as well as their wives, children, and mistresses necessitates their acts of violence. For example, when an attempt is made on Michael Corleone's life in The Godfather II, he is not just concerned because someone tried to assassinate him, he is enraged because the gunshots were fired into his bedroom: "Where [his] wife sleeps. Where [his] children come and play with their toys." ${ }^{3}$ Likewise, Santino Corleone swears vengeance on his brotherin-law Carlos in The Godfather I because he beat up his sister Connie; and Tony "Scarface" Camonte kills his partner Little Boy only when he thinks Little Boy has taken advantage of his sister Francesca.

Both classic gangster films and later gangster films provide fertile ground to discuss female characterization, but I would like to focus on the rural/bandit sub-genre that emerged after the decline of the classic films. Shortly after the early films came out, their popularity attracted the attention of groups such the Catholic Church based Legion of Decency, and studios soon came under attack for not adhering to moral guidelines set forth in the Production Codes. These Codes were designed to limit what Hollywood could film and to protect audiences" "moral standards." 14 The enforcement of the Production Codes in the thirties changed the focus of the gangster genre from the fierce gangster who attacks society to the diligent and single-minded law enforcer who attacked criminals. According to Schatz, this shift caused the gangster genre to go "into a period of diffusion and decline .... and only occasionally was it able to recapture the visual style, characterization, and narrative complexity of the classic gangster sagas." 15

One type of film that came to replace the watered-down versions of the gangster narrative was the bandit film that emerged in the forties. ${ }^{16}$ Instead of depicting a hero at odds with his urban environment, these films portrayed "heroes of tragic proportion who reevaluated their past misdeeds but realized the inevitability of their fate .... Such an ambivalent portrait of the hero and his changing values is a great deal more complex morally and socially than that of the late-30s bandit precursors." ${ }^{17}$ Unlike the traditional gangster who truly believes that he will beat the system and get away with criminal behavior simply because he has the ambition to do so, the bandit hero self-consciously questions the role that he plays in society and understands the consequences of his criminal 


\section{Left History 6.1}

actions. This self-awareness is the key difference between the bandit films and the classic gangster films, and because of it the rural outlaw developed into the perfect character to criticize social mores and conventions.

If the rural/bandit character was ideal character to question issues of authority, then Arthur Penn was the ideal director to utilize the genre's potential. Early in his career as a filmmaker he discussed his theories about, and motivations behind, movie making by stating:

I would say that the only people who really interest me are the outcasts from society. The people who are not outcasts - either psychologically, emotionally, or physically - seem to me a good material for selling breakfast food, but they're not material for films. What I'm really trying to say through the figure of the outcast is that a society has its mirror in its outcasts. A society would be wise to pay attention to the people who do not belong if it wants to find out what its configuration is and where it's failing. ${ }^{18}$

Penn self-consciously employs characters who do not fit into mainstream society and in the process he manipulates generic mediums. ${ }^{19}$ Perhaps the best example of his directorial approach is found in Bonnie and Clyde (1967), in which he reinvents the bandit film, and in doing so, critiques gender ideologies. ${ }^{20}$ Robert Benton, who wrote the screenplay with David Newman, recognized that the film needed an American director and that Penn's work on the film was crucial to its success. ${ }^{21}$ As screenwriters they were "concerned with the mythology [of Bonnie and Clyde]," but as the director Penn was "concerned with the social context and commentary." 22 So, while the film is based on historical facts, it also plays around with those facts in order to address contemporary issues. Penn made this point clear when, before filming had begun, the studio decided to that in order to stay true to the historical period of the subjects the film would be shot in black and white. He explains that both he and Warren Beatty (who both starred in and produced the film) refused: "Absolutely not. It's got to be a film about now. This is not a re-creation of Bonnie and Clyde, they were a couple of thugs. We're talking about two kind of paradigmatic figures for our times." 23 Because Bonnie Parker and Clyde Barrow were outlaws and outcasts from society, and because Penn admitted that his goal was to question the social order that existed in his own generation, it is appropriate to argue that Penn uses the story of Bonnie and Clyde, the Depression era outlaws, to reflect the cultural attitudes of the sixties. In order to understand how the characters of Bonnie and Clyde function as a reflection and 
criticism of the sixties culture, I will analyze historical accounts of Bonnie Parker as well as information concerning the women's movement. A comparison of the original story to the modifications or embellishments that Penn made in the movie will bring to light issues critical to the women's movement, especially the sexual revolution that was under way in the sixties. ${ }^{24}$

Early in the sixties, the government of the United States started to become more actively aware of women's issues. In 1961 President John F. Kennedy, following recommendations of Assistant Secretary of Labor Esther Peterson, "established a commission on the status of women to create a plan to help women fill their dual public and private roles." As a direct result of this commission, Congress passed legislation in 1963 "prohibiting differentials by sex in wage rates in private industry," which was "the first such employment discrimination law."25 While women's issues were being recognized on a federal level, they were also being addressed on a social level, and various individual women formed independent groups to continue the discussion surrounding gender concerns. In this same year Betty Friedan published her ground-breaking book Feminine Mystique. Friedan claims that she wrote the book in order to bring women's rights to the "national consciousness and personal consciousness." She goes on to add that:

[Women] were in the era when there was only one image of woman: woman defined only in sexual relation to men - men's wife, mother, housewife, sex object, server of physical needs to husband, children, home. This was absolutely so prevailing that each woman thought there was something wrong with her .... My book, and others that followed it, broke through that obsolete definition of women that was limiting their vision of their own possibilities and necessities to move in society as a whole. $^{26}$

Friedan, and other women committed to these same goals, went on to form the National Organization of Women in 1966.

NOW was not the only organization that worked to advance women's rights. Alice Echols explains that the Civil Rights Movement was a large factor that figured into the women's rights movement because while women worked with blacks to abolish racist laws for organizations such as the Student Nonviolent Coordinating Committee (SNCC) and Students for a Democratic Society (SDS), they began to question their participation. ${ }^{27} \mathrm{~A}$ majority of them were given stereotypical women's work, such as cooking and secretarial jobs, while the men were doing fieldwork in leadership positions. But, as movement 


\section{Left History 6.1}

activist and sociologist Wini Breines explains:

It is impossible not to be aware of how shaped we were by the Civil Rights movement ... and how crucial our participation was. I wondered at the time how it could be that women were subordinate in those movements and yet often were not clearly conscious of it. For a time, it seems, the excitement of our own activism and ruptures with our pasts, the new experiences of feeling strong and purposeful overwhelmed the recognition of sexism. ${ }^{28}$

As women became aware of their desire to contribute more to SNCC and SDS, they also began to recognize their need to actively promote women's rights and they began to borrow from the groups' theory to form their own organizations to discuss political and social reform for women. One of the tenets that women based much of their work on was that a group "must organize around their own oppression." ${ }^{29}$

As women began to feel more socially empowered, they also became more comfortable with their sexuality and wanted to extend the limits of what society felt was appropriate for women. Women were able to question their sexual roles not only because they were gaining more social and political power, but also because they were securing more control over their bodies. Women were able to meet this goal after Gregory Pincus successfully developed the birth control pill in the late fifties. By 1966, six million American women and another six million around the world were taking the pill. Obviously, birth control allowed women to take more control of their bodies and they could experiment with sex without worrying about pregnancy. Women, such as Ambassador Clare Booth Luce, openly praised the pill and said of it, "Modern woman is at last free as a man is free, to dispose of her own body, to earn her living, to pursue the improvement of her mind, to try a successful career." 30

While this new found sexual freedom was generally seen as a large step forward for the women's movement, it also spawned conflicting opinions among individual women. Some, like the author of Personal Politics, Sara Evans, felt that men expected women to adopt their "own more promiscuous sexual standards," and that women were exploited rather than liberated by the sexual revolution. ${ }^{31}$ Others, such as Deidre English, pointed out that those who dismissed the sexual revolution as an event that exploited women did not recognize the opportunities it could provide them. She says: 


\begin{abstract}
My recollection of it is that it was not an unmitigated disaster. The sexism was there, but women were actually having more sexual experience of different kinds and enjoying it. Women were having sex that was not procreational, and claiming the right to it as well as paying a lower social and emotional cost. ${ }^{32}$
\end{abstract}

Echols points out that as women debated back and forth about sex, men also questioned their new role as the revolution gained momentum; would they have to become less sexual as women became more sexual? ${ }^{33}$ The questions that both men and women posed about women's sexuality and changing gender roles in the sixties are addressed in Bonnie and Clyde.

The use of historical figures to question contemporary gender issues presents itself in the opening sequence of Bonnie and Clyde with the editing together of several snapshots. These photographs depict people in the Depression era, with the images gradually shifting from old people, to younger people, to pictures and short biographies of Bonnie Parker and Clyde Barrow. The contrast between these images of traditional and rural life, and the next shot - an extreme close-up of Bonnie's lips while she puts on lipstick - emphasizes the generation gap that existed in the sixties. Penn himself describes this opening sequence as "a close-up of her hungry lips ... that's what it is - a hunger for something more than her present existence." 34 Bonnie's dissatisfaction with her situation is further emphasized as the camera draws back from Bonnie's lips and we are given first a view of her face, and then her naked body. She demonstrates her boredom and frustration with the domestic sphere as she moves from the mirror and throws herself on her bed. Her act of beating on the bars of the bed and then grasping them to pull her face up between them suggests that she feels imprisoned by her present situation of living at home and working as a waitress. ${ }^{35}$ This is further emphasized when she stands in front of the window. The focus shifts from an interior to exterior shot, and we see Bonnie encased by the window, with the ledges covering her breasts and thighs. Her complete enclosure in the window frame not only suggests that her captivity springs from her leashed desire, but that she also is framed metatextually as an inconographic representation of the sixties' liberated woman.

In Born to be Wild: Hollywood and the Sixties Generation, Seth Cagin and Philip Dray point out that Faye Dunaway was required to lose thirty pounds in order to play Bonnie in the film. ${ }^{36}$ This careful attention to Bonnie's body pays off. Her thinness and bony ribs not only draw attention to the fact that the story is set in the Depression when people literally did not have enough money to eat, but also to changing notions of the ideal female body that arose in the sixties 
with women such as Twiggy, Jane Fonda, and Brigitte Bardot. While Dunaway dazzles the audience as a sexual image, Bonnie's nudity, sexuality, and autoeroticism dazzle Clyde. The last sequence of our introduction to Bonnie is when she hurriedly pulls a dress out of her closet (the closet door has a picture of a house on it), throws it on, and runs out to meet Clyde. Bonnie literally runs away from home and the domestic sphere. The low angle camera shot from the bottom of the stairs is not there to show us Bonnie's expression or feelings about meeting this mysterious man who's trying to steal her mother's car. Rather, the camera's voyeuristic gaze up Bonnie's dress as she races down stairs emphasizes that it is Bonnie's sexuality and desire to escape from the life that her mother led (as shown in the snapshots) that leads her into a life of crime with Clyde.

This interpretation becomes clearer when compared to the real story of Bonnie Parker and Clyde Barrow. E.R. Milner explains that Bonnie had married when she was sixteen (she had a tattoo on her upper thigh that had her and her husband's name in a heart) and her husband went to jail for robbery within a few years of their wedding. In order to make ends meet Bonnie was employed as a waitress in West Dallas, Texas, but when the cafe where she worked closed down she agreed to she take a job caring for a neighbor who had broken an arm. It was while she was in her friend's home that she met Clyde. They were instantly attracted to each other and began corresponding. When Clyde went to jail, Bonnie lied to her mother and left town to break him out by sneaking a stolen gun into his cell. She met him when he got away from the prison, and at this point they began their life of crime together. ${ }^{37}$ Although this is certainly not the most common way of meeting someone, Bonnie and Clyde's introduction, and the beginning of their relationship, pales next to the erotic and exciting meeting presented in the film. Penn admits that the opening of the film was completely fabricated and states that "We made conjectures about their intimate life, because we didn't know much about it .... But we do know that he was deeply devoted to her." ${ }^{38}$ Penn openly admits basing a film around a subject about which he did not have thoroughly documented information, and this demonstrates that his agenda of questioning social order begins with his portrayal of Bonnie as a sexual, liberated woman.

In From Reverence to Rape: The Treatment of Women in the Movies, Molly Haskell argues that in sixties films, "There is only sexual liberation or nonliberation, either/or, nudity or full dress. And when [women were] 'liberated' on the screen - that is, exposed and made to be sexually responsive to the males in the vicinity - it was in order to comply with male fantasies ... or to confirm men's worst fears." ${ }^{39}$ In this context, Bonnie's nudity on screen would not serve to question views about women's sexuality but would only perpetuate 
the dominant culture's perception of women as solely sexual objects that should gratify male desire. Clyde represents the male fear of overt female sexuality and what his role should be. Although Haskell suggests that Bonnie's sexual openness exists to satisfy the male gaze and audience, I would argue that her sexuality also establishes a woman's need to satisfy herself, despite Clyde's fears and society's disapproval. The image of her on the screen does not play into male fantasies regarding the female body, but rather her presence as a fully sexual woman, within the context of the women's movement, affirms women's rights to exert sexual desire.

This idea is further substantiated in the next few minutes of the film during which Bonnie becomes increasingly interested in Clyde's stories about prison. She expresses her doubt about his claim that he served time and, in what Nancy Cott describes as "possibly the film's sexiest moment," Bonnie runs her tongue over the top of a coke bottle while Clyde pulls out his gun. ${ }^{40}$ The camera zooms in for a close up as she fondles the weapon and sighs. Critics such as Robert Toplin have focused on Clyde's impotency and suggest that Clyde's gun represents his displaced sexuality, with the firing of the gun symbolizing ejaculation. ${ }^{41}$ While this interpretation is valid, it neglects to mention Bonnie's response to Clyde's gun. She admires his weapon, and therefore his sexuality, but she also taunts him by saying, "But you wouldn't have the gumption to use it." Her tone suggests that not only she is very aware of her own sexual power and longs to express it, but that she also doubts Clyde's ability to not only deal with her sexuality, but also his own.

Bonnie's fascination with Clyde's dangerous lifestyle is what initially draws her to him, but she soon realizes that she will have to embrace his criminality, rather than his body, to find sexual gratification. Surprisingly, Clyde rejects Bonnie's bold advances and informs her that he "is no good as a lover boy." $\mathrm{He}$ bluntly informs her that she should have more respect for herself. While it is obvious that Bonnie's resents his rejection, his offer to take her away from her small town and dress her in silk, simply because she "may be the best damn girl in Texas," appeals to her. Echol's point that men felt uncomfortable with the sexual revolution is evident here - Clyde becomes less sexual as Bonnie becomes more assertive. But despite Clyde's impotency, he still welcomes Bonnie as an equal partner. They both take part in the crimes, and Bonnie's desires are not ignored, but rather displaced on to their violent acts.

Bonnie knows that Clyde is impotent and afraid of initiating a sexual union, but she never gives up trying to engage in sexual activity. After Clyde kills a man, in a bumbled bank robbery, he gives her a choice about either going home to her mother or staying with him; she refuses to leave him and he rewards her 
loyalty with a display of physical affection. Clyde backs off after only a few kisses, but Bonnie continues to attempt to make love to him and even initiates oral sex. Clyde's uneasiness with Bonnie's advances is highlighted by the lack of extradiegetic sound. The only noise we hear is natural sound, such as the creaking of the bed as they shift positions and their breathing, and this lack of a musical soundtrack stresses Bonnie's passion and Clyde's lack of desire. Clyde finally stops her advances and instead of the male gaze being satisfied, there is a sense of relief for the audience. His voice reiterating that he isn't much of a lover boy breaks the silence, and we are rescued, for a moment, from witnessing this palpable sexual tension. Bonnie's voracious sexuality does not serve to gratify the male audience, but rather exists to illustrate the sexual tension raised by candid female desire. Because this issue cannot be resolved in the bedroom, it is instead worked out in their robberies.

Newton and Benton claim that they purposefully created characters who would appeal to the youth culture of the sixties. After the film was made they asserted:

If Bonnie and Clyde were here today, they would be hip. Their values have been assimilated in much of our culture - not robbing banks and killing people of course, but their style, their sexuality, their bravado, their delicacy, their cultivated arrogance, their narcissistic insecurity, their curious ambition have relevance to the way we live now. ${ }^{42}$

If Bonnie and Clyde represent the attitude of the youth, then there is no question that Sheriff Frank Hamer symbolizes the older generation. He signifies society's fear of not only youth questioning social authority, but also its uneasiness about a sexually independent woman. Milner points out that in fact the real Hamer never met Bonnie and Clyde and actually had to have another law officer confirm their identities at the ambush sight. ${ }^{43}$ Penn's decision to create a scene in which Hamer meets the outlaws signifies the importance of how the social outcast questions the establishment. When Hamer first meets the Barrow Gang, he attempts to sneak up on them from behind their car. Clyde spots him and shoots his gun out of his hand. After Clyde berates him for not doing his job - "protecting poor folk" - the group argues about what to do with him. Buck suggests shooting him while C.W. Moss thinks they should hang him, but it is Bonnie who comes up with the solution: "Let's take his picture." Bonnie's decision to humiliate him, by not only having her picture taken with him, but also by running the tip of her gun over his mustache and then kissing him full on the mouth, rejects the cultural attitude that women should restrain their sexual 
appetites. Hamer does not show any emotion throughout the whole scene, until after Bonnie kisses him when he spits in her face. His disgust for, and disapproval of, the Barrow Gang's law breaking is insignificant compared to his contempt for Bonnie's open sexuality. Another character who reflects this same opinion is Malcolm Moss. He is cordial and welcoming to Bonnie and Clyde but when alone with his son C.W., he declares his loathing of the couple, and particularly Bonnie. He says, "What does Bonnie know, she ain't nothin' but cheap trash herself." Malcolm despises Bonnie for getting his son involved with crime, and his dislike for her motivates him to conspire with Hamer. Malcolm not only wants to protect C.W., he also wants Bonnie disciplined for her active participation in their criminal lifestyle. ${ }^{44}$

While Hamer and Malcolm dislike Bonnie, Bonnie's mother loves her daughter but realizes that others do disapprove of her career choice and will not allow her to continue to threaten mainstream society. Clyde tells Mrs. Parker that Bonnie told him that after they quit running from the law she "couldn't bear to live more than three miles away from [her] precious mother." When Clyde asks Mrs. Parker if she would enjoy having Bonnie live near her, she replies, "I don't believe I would. I surely don't. You try to live three miles from me and you ain't gonna live long, honey. You best keep running ... and you know it." For Bonnie, sexuality and criminality are synonymous, and society will not let a criminal/sexual woman settle down in a community, and her mother, a member of the older generation, knows this and warns her.

As James Lynn points out: "The average cinematic construction of the feminine is an effect of male-orchestrated signs, code, and conventions that have established themselves in the perception of male and female audiences as normal." ${ }^{45}$ So, even though Bonnie mediates the progressive gender ideologies of the sixties, she also is presented in the traditional mode of filmmaking and must comply with the formal structure of the gangster genre. The focus of the genre's narrative is on the male individual, so the female character has to draw attention to his struggle. Despite his sexual impotency, Clyde's devotion to Bonnie and his desire to protect her are paramount to the story line. He informs Bonnie's mother that he has purposefully passed up jobs that would have been lucrative because they posed a threat to Bonnie's safety, when he says, "I ain't gonna risk my little girl here just to make money, uncertain as times are," and when Bonnie runs away from him he panics. These tender moments between the couple are juxtaposed with the criminal scenes where Clyde's violent and dangerous nature comes out. As the tale progresses we see less and less of this side of Clyde as the focus of the film shifts to their relationship. Schatz argues that unlike the classic gangster genre, in the rural bandit story line, "the hero's 
transition ... from hardened, cynical gangster to humane, sensitive lover taxes the genre's demand of moral retribution." 46 This shift in narrative locus complicates the ending of the movie because once they have settled down for a little while with the Moss family, after Buck has been killed and Blanche blinded, their crimes are pushed to the background of the narrative and are diminished in the audience's mind.

Instead of daring robbery scenes and fast get-a-ways, the end of the movie is filled with scenes of Bonnie and Clyde having quiet, casual conversation. Once Bonnie has accepted Clyde's impotency she turns to writing poetry for further validation. This aspect of the character of Bonnie is in keeping with the real Bonnie Parker. Dallas County Deputy Sheriff Ted Hinton, who first met Bonnie in 1929 when she was a waitress, claims that when Bonnie was young "she wanted to be a singer ... or maybe an actress or poet." ${ }^{\text {"47 }}$ Penn utilizes the original Bonnie's dramatic flair and poetic ambition to represent how Bonnie, the character, needs to express herself with words. This characterization mirrors how real women strove to affirm their intellects and establish a "voice" or selfrepresentation. In the film Dunaway reads, "The Story of Bonnie and Clyde," or as it is also known "It's Death," the actual poem that the real Bonnie composed and sent to newspapers for publication. ${ }^{48}$ The stylistics of the poem are simple and Dunaway's slow, faltering recital of it only emphasizes its childlike qualities and draws attention to her initial steps toward recognizing and asserting her own significance in their narrative. We hear their story from her female perspective and therefore have to acknowledge her vital role in their criminal activities and in their rise to legendary status in American history.

The poem's form is elementary, but its function is complex. It establishes Bonnie's narrative position, which is essential to the film's depiction of her as a reflection of sixties gender politics, and it also fulfills the expectations of the genre because it refocuses the audience's attention to the protagonist. Clyde is obviously delighted with her homage, and she shyly revels in his praise. The personal importance that they place on the poem affirms Bonnie's first attempt at establishing her voice, but this significance is down played because Clyde is only able to recognize himself in work. He exclaims, "You know what you've done? You told my story. I told you one day I'd make you somebody and that's what you done for me. Made me someone that everybody will remember." The importance of the poem should lie in Bonnie's authorial voice, but ultimately it rests on the subject of Clyde.

Through his self-aggrandizement Clyde overcomes his fear of intimacy and finally initiates sex. He moves in to kiss her and the camera ignores their lovemaking. The audience is shut out of this encounter as the lens follows the 
discarded newspaper, and poem, blowing away in the wind. Their union is now normalized because it is finally Clyde who expresses desire rather than Bonnie. Bonnie's sexual satisfaction, which was foregrounded in the beginning of the film, takes a back seat to Clyde's empowerment and once their sexual desires have been recognized, she no longer has the need to continue committing crimes and running from the law. This point is accentuated when the extradiegetic music that has always played during their criminal escapades begins; the repetition of this music highlights the fact that for Bonnie, sex and crime have existed in the same realm. The demands of the genre are met because Clyde becomes the hero whose social power stems not only from his robberies and killings, but also from his romantic and sexual command.

Despite the shift in their motivations, and the audience's new sympathy for the doomed couple, Frank Hamer tracks them down, determined to punish them. By the end of the film it is apparent that Bonnie and Clyde's sexual consummation has tamed Bonnie's sexual assertiveness, so the audience almost forgets that this issue exists and has to be addressed in the closing scenes. But Penn subtly reminds us when Bonnie fishes around in the back seat for a pear. She takes a bite from the fruit and then carefully feeds Clyde as they take their last drive together down a dirt road in Arcadia, Louisiana. Immediately following this Adam and Eve like scene, in which we are reminded that the root of the film's tension lies in Bonnie's sexuality, Hamer and his men ambush Bonnie and Clyde. The shot-reverse-shot sequence of extreme close-ups of Bonnie and Clyde's eyes as they share the recognition that they are going to be killed restates their close bond and equal partnership. The very last image of Hamer, dressed in the traditional villains' black clothes, framed by the bulletridden car window, reiterates that he punishes Bonnie and Clyde not only for their criminal acts, but also for their lack of respect for authority, and for the sexual humiliation he has suffered at their hands. Mainstream society's unease with the phenomenon of Bonnie as a sexually uninhibited woman is presented on how the "problem" of Bonnie Parker is dealt with. She is punished in the end by the law not only because she was a criminal, but also because the social order did not know how to deal with a woman who wanted to settle down and at the same time acted on her sexual desires.

Society's harsh punishment for a woman like Bonnie becomes even more evident with a comparison of her character to that of Blanche Barrow, the minister's daughter who's married to Clyde's brother Buck. A blatant recognition of the differences between the two women is especially evident when they meet for the first time. Buck, who is overjoyed to be reunited with his brother, insists that they take family pictures. When Clyde photographs the couple, Blanche 


\section{Left History 6.1}

coyly giggles, worries over her appearance, and affects horror at the prospect of being captured on film. Bonnie, on the other hand, gives Blanche a look of disdain, grabs a gun, defiantly chomps on a cigar, and stands proudly in front of their car. The pose she adopts replicates the photographs of the real Bonnie that police developed from a roll of film the Barrow Gang left behind in Joplin. When the photographs were published in the Fort Worth Star Telegram, with the description of Bonnie as a cigar-smoking moll, Bonnie wrote a letter to the editor asking them to retract the statement. In fact, she so adamantly despised the unfeminine image that the press presented that when a released hostage asked Bonnie what she wanted him to tell the newspapers about her, she replied: "Tell them I don't smoke cigars." ${ }^{\text {A9 }}$ Although Penn remains true to the poses presented in the historical photographs, he notably disregards the concern that the real Bonnie expressed about them. Instead, he plays up the tough, seductive image of the gun-wielding woman in order to stress the sexual tension that pervades the film. And he reinforces this notion of Bonnie asserting herself as a promiscuous character by creating the scene in which Bonnie has Clyde take pictures of her kissing Frank Hamer. Significantly, while Bonnie plays the temptress, Blanche refuses to take part in the Hamer humiliation.

Blanche's compliance with mainstream society's gender expectations is not only evident in her chaste and domestic demeanor, but is also unmistakable in her embarrassment at seeing C.W. in his underwear, her enthusiasm for her marital relationship, and her excitement about their rented apartment in Joplin. The dichotomy between the two women is glaringly, and humorously, highlighted when the law discovers the Barrow Gang's hideout and surrounds them in Joplin - Bonnie escapes from their house with a gun, whereas Blanche screams hysterically and runs away with an apron on and a spatula in hand. Bonnie also smugly berates Blanche for her conservative domesticity and makes fun of her hillbilly ways.

Despite her refusal to participate in all of the gang's escapades, Blanche does gradually develop a new attitude toward their unusual lifestyle. For example, Blanche starts wearing pants and, in an apparent nod to sixties' fashion, she dons a pair of round, rose-colored sunglasses that Buck stole from a bank security guard. She also demands a cut from their earnings because she "risks her life just like everyone else and has to put up with sass from Miss Bonnie Parker." So while Bonnie begins to depict a more moderate view of femininity in order to adhere to the demands of the genre, Blanche begins to accept her criminal situation and gradually reflects some of Bonnie's more broad-minded attitudes.

This transition only draws more attention to the risks that a woman takes in 
seeking acceptance from mainstream society while still adhering to nontraditional gender roles. Luckily for Blanche, her unwillingness to completely transform herself into an all-out criminal is noted by Hamer. The authorities know that she does not fully participate in the gang's escapades, and their knowledge influences how they choose to deal with her. After a shoot-out in some tourist cabins, the gang finds themselves surrounded in a field. Buck and Blanche are both injured and are not able to escape with Bonnie, Clyde, and C.W. In spite of the fact that more men with more firepower take part in this ambush than in the ambush in Joplin, Blanche survives. The police focus their fire at Buck and kill him instantly, but they never even take aim at Blanche. Blanche's filmic character has to live in order to remain true to actual historical events, but Penn's careful attempt to point out the differences between Bonnie and Blanche's compliance to accepted gender roles suggests that Blanche's refusal to completely abandon society's expectations about gender roles saves her from death, while Bonnie's aberration from accepted social mores leads inevitably to her destruction.

While the ending of the film emphasizes the hazards of questioning gender ideology, it also fills the formal demands of the genre. It is only after the audience sympathizes with the protagonists, and the protagonists themselves have recognized their fate, they are killed. This adherence to the medium highlights the political subtleties of the film and also strengthens the socializing influence of genre. As Tudor suggests, "the genre concept is indispensable in more strictly social and psychological terms as a way of formulating the interplay between culture, audiences, films and filmmakers." 50 This interplay between the film and the audience of film critics became a central point in the success of Bonnie and Clyde. Initially critics expressed disgust with the film because of the startling displays of violence, criminality, and sexuality, and Pauline Kael, perhaps the earliest and staunchest supporter of the film, claims that the "movie had been panned as an insult to the audience, as bloody and offensive, by just about every major critic in the country." She goes on to add that a positive review from The New Yorker came as "quite a shock to people," especially because the review was "coming from a woman." 51 But the more critics complained about the film, the more the public went to see it. Kael points out that movie critics "tend to exalt works that we're emotionally and intellectually ready for. And we expect the audience to be in the same spot in their lives as we are .... The most a critic can do is to try to understand the audience's responses - and maybe try to enlarge them a teeny bit." 52 In the case of Bonnie and Clyde, audiences were more prepared for the social messages, and in an unprecedented move critics, such as Newsweek's Joe Mergenstern, 


\section{Left History 6.1}

reversed their early negative reviews. ${ }^{53}$

One critic, who hated the film and did not change his opinion of the film as it gained popularity, was Bosely Crowther from The New York Times. He not only refused to hedge on his original opinion of the movie, but he also wrote more than one review blasting it. One of his most immediate concerns was that

[Bonnie and Clyde] has Mr. Beatty clowning broadly as the killer who fondles various types of guns with as much nonchalance and dispassion as he airily twirls a big cigar, and it has Miss Dunaway squirming grossly as his thrill-seeking, sex starved moll. ${ }^{54}$

Even though Crowther criticizes both Beatty and Dunaway, the adjectives that he uses to describe Dunaway are much more negative, which suggests that her sexuality offends him more than Clyde's criminality. Penn admits that he was "delighted" by Crowther's attacks because they not only provided much-need publicity, but also because they proved that his own artistic intentions "were misunderstood by people who should have misunderstood." 55 The older generation, or establishment, that Crowther represented were repulsed by the message of overt sexuality and violence, while members of the younger generations honed in on the social/sexual implications of the film.

This depiction of the two outlaws as rebellious youth was not the only reason for the film's success. Another key factor in drawing young people to the film was that advertisers purposefully marketed the film to that segment of the population. Lobby cards for the film featured a sepia-toned picture of the Barrow Gang as well as a short biography of them. It read:

Clyde was the leader. Bonnie wrote poetry. C.W. was a Myrna Loy fan who had a bluebird tattooed on his chest. Buck told corny jokes and carried a Kodak. Blanche was a preacher's daughter who kept her fingers in her ears during the gunfights. They played checkers and photographed each other incessantly. On Sunday nights they listened to Eddie Cantor on the radio. All in all, they killed 18 people. They were the strangest damned gang you ever heard of.

At first, this seems like it could be a description of any group of fun-loving young people, until its casual mention of the gunfights and the number of murders they committed. This technique appears in another poster that features a black and white shot of Clyde driving a car. He has one hand on the steering wheel and his other is wrapped around Bonnie. She is leaning into him with her 
head thrown back and they both appear to be laughing. They look like any normal, young happy couple except that we are looking at them through a bulletridden car window. Above and below the image are the words: "They're young, they're in love, and they kill people." ${ }^{\text {"E }}$ Each of the advertisements explicitly links youth, sex, and violence.

Advertisements influenced the perception of the film, and the stars in the movie did as well. This was Faye Dunaway's big break into mainstream movies, but Warren Beatty was already well known. The very fact that Beatty played the role of Clyde draws attention to the sexual tension that pervades the film. He was known as a lady's man who slept with all of his leading women and a man known for sexual prowess playing an impotent character would obviously bring attention to the leading actress who exudes sexual assertiveness. The combination of youth and sexual responsiveness challenges the social order and threatens to subvert gender ideology. As Pauline Kael points out:

Bonnie and Clyde brings into the almost frighteningly public world of movies, things that people have been feeling and saying and writing about. And once something is said or done on the screens of the world, once it has entered mass art, it can never again belong to a minority, never again be the private possession of an educated 'knowing' group. But even for that group there is an excitement in hearing its own private thoughts expressed out loud and in seeing something of its own sensibility become part of our common culture. ${ }^{57}$

The people involved in the women's movement had to have recognized that the issues and rights that they were fighting for were being addressed in the film, and must have felt a sense of affirmation that what they were striving for was possible. Although Bonnie is killed for acting out her sexuality, the issue was at least being addressed in a public medium. Clyde's speech to Bonnie, when he convinces her to stay with him, addresses the issues of women's sexual and intellectual capabilities:

All right, all right. If all you want's a stud service then you go on back to West Dallas and you stay there the rest of your life. You're worth more than that, a lot more than that, and you know it. And that's why you come along with me. You can find a lover boy on any damn corner in town and it don't make a damn to them whether you're waiting on table or picking cotton, but it does make a damn to me! ... Because you're different ... you want different things. You want something better than being a waitress. You and 
me traveling together could cut a path clean across this state, and Kansas, and Missouri, and Oklahoma!

Clyde's prediction is true. Not only do they create a sensation throughout the Southwest with their criminal and violent acts, they also bring national attention to the struggle that women face in claiming the right to express their social and sexual desires. The portrayal of the sexual woman in Bonnie and Clyde in no way answered all the questions that the sexual revolution raised, but the strength of the film lies in the fact that it addressed the complexities that both men and women faced in negotiating issues of gender and sexuality. As Richard Burton explains, "the outrage that greeted Penn's reinvention of the gangster film may be difficult to grasp. Yet the calumny that was heaped upon Bonnie and Clyde ... helped to crystallize generational, political, and social conflicts that went to the heart of the late Sixties' unprecedented cultural upheaval." 58

1 Stella Bruzzi, "Style and the Hood," Sight and Sound, 5 (Nov. 95), 26-7.; Thomas J. Ferraro, "Blood in the Marketplace: The Business of Family in The Godfather Narratives," in Werner Sollers, ed., The Invention of Ethnicity (New York 1989), 176208.; William Simon, “An Analysis of the Structure of The Godfather, Part I," Studies in the Literary Imagination, 16.1 (Spring 1983), 75-89.

2 The formal and ideological roles are not, of course, mutually exclusive, but I am using the term "ideological" heuristically. While the formal role of the female characters is grounded in the ideology of the thirties, the public discourses surrounding gender throughout its life span influences the ideological shifts in female characterization.

3 Laura Mulvey, "Visual Pleasure and Narrative Cinema" in Robyn R. Warhol and Diane Price Herndl, eds., Feminisms: An Anthology of Literary Theory and Criticism, (New Brunswick, N.J. 1993), 433.

4 Jack Ellis, The History of Film (Boston 1990), 156.

5 Thomas Schatz, Hollywood Genres (New York 1981), 11.

6 Andrew Tudor, "Genre and Critical Methodology," in Bill Nichols, ed., Movies and Methads (Berkeley 1976), 122.

7 Little Caesar, Mervin LeRoy (dir.), Edward G. Robinson, Douglas Fairbanks, Jr. (perf.), (Warner Bros., 1930).; Scarface, Shame of the Nation, Howard Hawks (dir.), Paul Muni, George Raft, Ann Dvorak (perf.), (United Artists, 1932).; The Public Enemy, William A. Wellman (dir.), James Cagney, Jean Harlow, Edward Woods (perf.), (Warner Bros., 1931).

8 Cited in Pam Cook, The Cinema Book (London 1994), 61.

9 The Godfather I, Francis Ford Coppola (dir.), Marlon Brando, Al Pacino, Robert Duvall, Diane Keaton (perf.), (Paramount Pictures, 1972). 
10 Scarface, Brian De Palma (dir.), Al Pacino, Steven Bauer, Michelle Pfeiffer (perf.), (Universal Pictures, 1983).

1l Get Shorty, Barry Sonnenfeld (dir.), John Travolta, Gene Hackman, Rene Russ, Danny DeVito (perf.), (MGM, 1995).

12 Robert Bray, "The Thematic Paradigm," in Sona Maasik and Jack Solomon, eds., Signs of Life in the U.S.A.: Readings on Popular Culture for Writers (Boston 1994), 243.

13 The Godfather II, Francis Ford Coppola (dir.), Al Pacino, Robert De Niro, Robert Duvall, Diane Keaton (perf.), (Paramount Pictures, 1974).

14 Schatz, Hollywood Genres, 95-98.

15 Ibid., 99.

16 Some well-known films that portray the shift in the portrayal of gangsters include: Angels with Dirty Faces, Michael Curitz (dir), James Cagney, Pat O'Brien, Humphrey Bogart (perf.), (First Nations Pictures, Inc., 1938).; Key Largo, John Huston (dir.), Humphrey Bogart, Edward G. Robinson, Lauren Bacall (perf.), (Warner Bros., 1948); and White Heat, Raoul Walsh (dir.), James Cagney, Virginia Mayo, Edmond O'Brien (perf.), (Warner Bros., 1949).

17 Schatz, Hollywood Genres, 103.

18 Cited in John Wakeman, ed., World Film Directors, 2 vols. (New York 1945, 1985), 769.

19 For example, in The Left-Handed Gun (1957) Penn subverts notions of masculinity in his Freudian reinterpretation of Billy the Kid, and in Little Big Man (1970) he offers a rendering of Western American history which depicts the inherent racism of the expansionist movement.

20 Bonnie and Clyde, Arthur Penn (dir.), Warren Beatty, Faye Dunaway, Gene Hackman, Estelle Parsons (perf.), (Warner Bros., 1967).

21 Christian Kealthy, "Robert Benton," in Film Comment, 31.1 (Jan./Feb., 1995). In this interview Benton also explains that after reading a book about John Dillenger, and watching Gun Crazy (1950), Breathless (1959), The 400 Blows (1959), and Shoot the Piano Player (1960) he and Newman were inspired to write an "American New Wave movie about Bonnie Parker and Clyde Barrow." Therefore, an American director was essential.

22 Gary Crowdus and Richard Porton, "The Importance of a Singular, Guiding Vision: An Interview with Arthur Penn," in Cineaste, 20.2 (1994).

23 Cited in Crowdus and Porton, "An Interview."

24 Other films based on the legendary couple, such as The Bonnie Parker Story (1958), also present Bonnie as a sexually voracious character. In fact, any account of the Barrow Gang would naturally offer this representation because the real Bonnie Parker was known for her sexual promiscuity. What makes Penn's film stand out is his admitted attempt to use the legendary couple to specifically address the politics of the sixties.

25 Cynthia Harrison, "From Home to the House: The Changing Role of Women in American Society," in U.S. Society and Values (Washington 1997).

26 Cited In Jennifer Chapin Harris, "After the Mystique is Gone: A Phone Interview with Betty Friedan, March 19, 1997," in Off Our Backs, (Oct. 97).

27 Alice Echols, Daring to be Bad: Radical Feminism in America 1967-1975 (New York 1989). Wini Breines claims that Echols's book is the "only full-length history of the radical feminist movement." 


\section{Left History 6.1}

28 Wini Breines, “Sixties Stories' Silences: White Feminism, Black Feminism, Black Power," in NWSA Journal, 8 (Fall 1996).

29 Echols, Daring to be Bad, 41.

30 John Heiderny, What Wild Ecstasy: The Rise and Fall of the Sexual Revolution, (New York 1997), 31.

31 Cited in Echols, Daring to be Bad, 42.

32 Cited in Ibid., 43.

33 Ibid., 44.

34 Cited in Crowdus and Porton, "An Interview."

35 This scene not only addresses issues of sexuality, it also raises questions about women's economic status in the sixties. Bonnie is clearly unhappy about her financial situation and this is a theme that the film returns to, but this topic is beyond the scope of this article.

36 Seth Cagin and Phillip Dray, Born to be Wild: Hollywood and the Sixties Generation (Boca Raton 1994), 13.

37 E.R. Milner, The Lives and Times of Bonnie and Clyde (Carbondale, Ill. 1996), 1622.

38 David Zinman, 50 Grand Movies of the 1960s and 1970s (New York 1986), 211.

39 Molly Haskell, From Reverence to Rape: The Treatment of Women in the Movies (New York 1974), 340. Haskell has been recognized as the definitive critic in feminist and film studies.

40 Nancy F. Cott, "Bonnie and Clyde," in Mark C. Carnes, ed., Past Imperfect: History According to the Movies (New York 1996), 220.

41 Robert Brent Toplin, History by Hollywood: The Use and Abuse of the American Past (Chicago 1966), 147.

42 Cited in Lawrence L. Murray, "Hollywood, Nihilism, and the Youth Culture of the Sixties: Bonnie and Clyde (1967)," in John E. O'Connor and Martin A. Jackson, eds., American History/American Film: Interpreting the Hollywood Image (New York 1979), 237-256.

43 Milner, Lives and Times of Bonnie and Clyde, 142.

44 An interesting aspect of the scene between Malcolm and C.W., is that it humorously depicts the generation gap as it existed in the sixties. They argue about C.W.'s new tattoo - C.W. defends his right to get a tattoo because Bonnie likes it and Malcolm suggests that if C.W.'s mother could see him, she'd basically role over in her grave. The dialogue is timeless and we could easily imagine their argument taking place in any home where a teenage son is trying to impress a girl and the father is concerned about family image.

45 James Lynn, "Introduction," in Janet Todd, ed., Feminist Film Theory: The Problem of Women in Film (New York 1988), 10.

46 Schatz, Hollywood Genres, 103.

47 John Neal Phillips and Andre L. Gorzell, "Tell Them I Don't Smoke Cigars": The Story of Bonny Parker,' in Francis Edward Abernethy (ed.), Legendery Ladies of Texas (Dallas 1981), 164.

48 Ernest M. Raub, "Bonnie and Clyde: Their Lives and Their Victims," in The Missouri State Trooper Magazine, n.d., <http://www.mosta.org/magazine.htm>. "It's Death" is not the only poem that Bonnie wrote and sent out for publication and publicity. She also wrote "Suicide Sal," a poem with a similar theme and style, and the 
press appropriated the title as a nickname for her.

49 Phillips and Gorzell, 168, 172-3.

so Tudor, "Genre and Critical Methodology," 123.

5) Cited in Will Brantley, ed., Conversations with Pauline Kael (Jackson, Miss. 1996), 155-6.

52 Cited in "A Century of Moves: A Talk with Pauline Kael," Newsweek, (6 June 1998).

53 Christian Kealthy, "Robert Benton."

s4 Bosley Crowther, The New York Times Film Review, 1913-1968 (New York 1970), 3693.

55 Cited in Crowdus and Porton, "An Interview."

s6 Tim Dirks, "Bonnie and Clyde (1967)," in Greatest Films, n.d., $<\mathrm{http} / / /$ filmsite.org/>. This website contains an extensive review of the film as well as pictures of several Bonnie and Clyde movie posters.

57 Pauline Kael, Kiss, Kiss, Bang, Bang, (Boston 1968), 47.

58 Crowdus and Porton, "An Interview." 